\title{
“GENIT" AS EFFECTIVE DESIGN OF LEARNING MEDIA
}

\section{Mardiki Supriadi}

\begin{abstract}
There are two main approaches to using media in schools: students can learn "from" Media and technology, and they can learn "with" media and technology. The basis for The use of media and technology as a "tutor" in schools is "educational communication," that is the deliberate act of communicating content (teaching content) for students by assuming that they will learn something "from" this communication, so communication is not again free but controlled and conditioned for educational purposes. Findings on the impact of technologybased instruction in education can be concluded that technology as a tutor has a positive effect on learning, one of them is the student can complete a set of educational goals in less time than necessary in a traditional approach. However, these two approaches only make the task become easier but do not activate and facilitate them to think critical and higher learning. "Media Genit" uses a new approach as an approach that can optimize perspective-based cognitive processes, constructivism, which constitutes an environment in which the student as a designer thinks creative about content combined with real-world tasks, student learning content, enjoy the learning process, and recognize that they have created something that is valuable.
\end{abstract}

Keywords: Constructivism, "Media Genit”, Learning

\section{Introduction}

One of the main reasons for widespread attention is focused on media and technology in education today is a huge financial investment made in the media and technology in education around the world. For example, in Indonesia, education budget in the 2016 APBN has made history. Because, the education budget in APBN 2016 became the largest compared to previous years, where the education budget in APBN 2016 reached Rp 419.2 trillion or 20 percent of the total state expenditure of Rp 2,095.7 trillion. (Source: APBN 2016, processed by Sapulidi Research Center (SRC) NGO Sapulidi). 
Why is so much attention paid to media and technology within education? First, in correlation with the media, there are many problems that become the attention of students, parents, educators, government, and society in general. For example, questions about the effects of different media towards the cognitive and moral development of children. With regards to technology, people want to know if the various new technologies are more effective to teach and learn compared to a more traditional classroom approach, whether few technologies are more motivating than others, or at least, what technology could be used to improve access or reduce costs in education.

Despite so much attention paid to media and technology in education, unfortunately there are still many teachers who are not comfortable with moving from the learning orientation shifting from teacher-centered teaching to student-centered learning, and this kind of transformation requires considerable time and support (Fisher, Dwyer, \& Yocam, 1996), plus many media and technological innovations of false learning promises to make learning fun and easy teaching. Cognitive tools do not make these promises, either for students or teachers. Instead, cognitive tools activate complex cognitive learning strategies and critical thinking.

The purpose of writing this paper is the integration of Genit models in the 2013 curriculum could contribute in the formation of cognitive constructivism of students, one of the applicable application is using LEGO / logo.

\section{Genit Media}

There are two main approaches to using media in schools: students can learn "from" media and technology, and they can learn "with" media and technology (Jonassen \& Reeves, 1996). Learning "from" media and technology is often referred to terms such as television learning, computer-based instruction, or an integrated learning system (Hannafin, Hannafin, Hooper, Rieber, \& Now, 1996; Seels, Berry, Fullerton, \& Horn, 1996).

Apart from this approach, media have been introduced to schools because it is believed to have a positive effect on teaching and learning. The purpose of writing this paper is to design the learning media of Genit on fundamental education. For the purpose of this report, the media is defined as "all means of communication, in all formats." In this case, the media includes such diverse symbols such as print, graphics, animation, audio, and motion pictures. Technology is defined as "every objects or processes from humans that can be used 
to deliver the media." In this, technology includes a variety of phenomena such as books, movies, and the internet.

In correlation to education, the media is a symbol system, used by teachers and students to represent knowledge; Technology is a tool that allows them to share knowledge representation with others. Unfortunately, the meaning of media and technology in education is defined synonymously. The difference between media and technology should be clarified because, the impact must be understood. Here is an excerpt from the Sixth Edition of The Encyclopedia of Educational Research (Alkin, 1992) explains these differences:

Computer-based technology could not be considered a "media," because of the variety of programs, tools, and devices that can be used with them are not limited to certain symbol systems, or to certain classes of activities ...... in this case, the "computer" is actually "a few stagse of discovery" of many uses, media to create symbols, explore, and think in different domains. This matter is used to represent and manipulate symbol systems language, math, music - and to create symbolic products - poetry, mathematical proofs, compositions. (Salomon, 1992, p. 892)

The basis for the use of media and technology as a "tutor" in school is "educational communication," which is the deliberate act of communicating content (teaching content) to students assuming that they will learn something "from" this communication, thus communication is no longer free but controlled and conditioned for the purpose of education (Krendl, Ware, Reid, \& Warren, 1996).

Findings on the impact of technology-based instruction in education conclude that technology as a tutor has a positive effect on learning, one of them being the student can complete a set of educational goals in less time than necessary with a more traditional approach. Limited study and evaluation indicates that integrated learning systems are effective forms of the technology-based instructions that are very likely to play a bigger role in classrooms in the future, some experts suggest that "... the corresponding role for technology is not a teacher / expert, but rather, that of the extension's mind 'cognitive tool' "(Derry \& Lajoie 1993, p.5)

The media to optimize cognitive processes have been deliberately adjusted or developed to function as an intelectual helper, to activate and facilitate critical thinking and higher learning. In the media approach to optimize the cognitive processes, media and 
technologies provided directly to learners, is used to represent and express what they know. The student functions as a designer using media and technology as a tool for analyzing the world, accessing and interpreting information, organizing private knowledge, and represent what they know to others.

Ideally, a task or problem for a media application for optimizing the cognitive processes will lie in a realistic context with that result that is meaningful personally to the learner. And there are things that at least need to be considered about media and technology in education, which are:

Bringing media and technology to school can take advantage of the quality of strong motivation for children. The education system that utilizes this motivation for having the chance for success is much greater ...... Each media has a cognitive excess profile, and any media can be used to enhance other impacts. (Greenfield, 1984, p. 178)

In a media approach to optimize cognitive processes, information is not encoded in predefined educational communications which are then used to transmit knowledge to students. Indeed, with media to build cognitive understanding, the need for formalized learning system design process is reduced. Instead of specialists like designers learners shaping student learning through determined communication and interaction, media and technology provided directly to learners to use to represent and express what they know. Students themselves serve as designers using media and technology as tools for analyzing the world, accessing and interpreting information, organizing their personal knowledge, and represent what they know to others.

In recent years, learning theory has gone through what can be called "Paradigm shift." Constructivist learning theory gradually gets a sense of the same respect and long attention given to the theory of behavioral learning (Duffy \& Jonassen, 1992). Constructivism concerns the process of how students are creating meaning and knowledge in the world as well as the result of constructive processes.

Media to optimize cognitive processes based on constructivism perspective offers a new paradigm in the world of learning. As the cornerstone of the learning paradigm, constructivism calls for the need for active participation of students in the learning process, the need for independent student development, and the need for students to have the ability to develop his own knowledge. The point is that with forming an environment where creative 
thinking about content is combined with real-world tasks, students learn content, enjoy learning, and recognize that they have created something of value.

To change students can learn "from" the media, to learn "with" Media based on the perspective of constructivism, it is necessary to find and improve the media design that exist today, so as to contribute in optimizing students' cognitive processes. As for the characteristic of the media is as follows:

1. GOOD, which is a good learning medium is to create an environment where creative thinking about content is combined with real-world work, students learn content, enjoy learning, and recognize that they have created something of value.

2. EFFECTIVE, which is learning media will have the greatest effectiveness when applied in a constructivist learning environment. The media to optimize cognitive processes based on constructivism perspectives can empower teachers to design their own knowledge.

3. NATURAL, namely: Designing learning materials that tell the natural phenomenon or environment.

4. INNOVATION, an innovative strategy of project-based learning.

5. TECHNOLOGY, which is a technology-based learning media.

To easily remember it, the author gave the Media Genit name which is the acronym of Good - Effective - Natural - Innovation - Technology.

\section{Conclusion}

The students can learn "from" the media, and they can learn "with" media, but these two approaches only make the task easier but do not activate and facilitate them for critical thinking and higher learning. Media Genit offers a new approach to the world of learning, which is transforming students from learning "from" the media, to learning "with" mediabased perspective constructivism, that is, shaping an environment, where students as creative content designers are combined with real-world tasks, student learning contents, enjoying the learning process, and recognize that they have created something of value.

\section{References}

Arsyad, A. (2013). Media Pembelajaran. Jakarta : PT Raja Grafindo.

Munadi, Y. (2008). Media Pembelajaran: sebuah pendekatan baru. Jakarta: Gaung Persada Press. 
Smaldino, S. E. et al (2011). Instructional Technology \& Media For Learning Teknologi Pembelajaran dan Media Untuk Belajar. Edisi Kesembilan. Jakarta : Kencana Prenada Media Group.

Rusman. (2012). Belajar dan Pembelajaran Berbasis Komputer, Mengembangkan Profesionalisme Guru Abad 21. Bandung : Alafabeta

Rusman, dkk. 2012. Pembelajaran Berbasis Teknologi Informasi dan Komunikasi: mengembangkan profesionalitas guru. Jakarta: Raja Grafindo Persada.

Johnson, E. B. (2007). Contextual Teaching and Learning. Bandung: MLC.

Schunk, D. H. (2012). Learning Theories and Educational Perspective, Yogyakarta: Pustaka Pelajar

David, J. L. (1996). Developing and spreading accomplished teaching: Policy lessons from a unique partnership. In C. Fisher, D. C. Dwyer, \& K. Yocam (Eds.), Education and technology: Reflections on computing in the classroom (pp. 237-250). San Francisco, CA: Jossey-Bass.

Jonassen, D. H. et al (1996). Learning with technology: Using computers as cognitive tools. In D. H. Jonassen (Ed.), Handbook of research for educational communications and technology (pp. 693-719). New York: Macmillan.

Hannafin, M. J. et al (1996). Research on and research with emerging technologies. In D. H. Jonassen (Ed.), Handbook of research for educational communications and technology (pp. 378-402). New York: Macmillan.

Alkin, M. C. (Ed.). (1992). Encyclopedia of educational research (6th Ed.). New York: Macmillan.

Salomon, G. (1992). New information technologies in education. In M. C. Alkin (Ed.), Encyclopedia of educational research (6th Ed.) (pp. 892-903). New York: Macmillan.

Krendl, K. A. et al (1996). Learning by any other name: Communication research traditions in learning and media. In D. H. Jonassen (Ed.), Handbook of research for educational communications and technology (pp. 93-111). New York: Macmillan.

Derry, S. J. et al (1993). A middle camp for (un) intelligent instructional computing: An introduction. In S. P. Lajoie \& S. J. Derry (Eds.), Computers as cognitive tools (pp. 1-11). Hillsdale, NJ: Lawrence Erlbaum.

Greenfield, P. M. (1984). Mind and media: The effects of television, video games, and computers. Cambridge, MA: Harvard University Press. 